\title{
Inhalt des zweiten Bandes
}

$\S 1$. Licht als Quantenerscheinung. . . . . . . . . . 4

$\S 2$. Gleichwertigkeit von Masse und Energie. . . . . . . . . 29

§ 3. Stoß mit Anregung . . . . . . . . . . . . . . 3t

§4. Dualität der Materie . . . . . . . . . . . . . . 45

$\$ 5$. Das magnetische Moment von Atomen, Elektronen und Kernen . . . . . . . . . . . . . . . . 60

$\S 6$. Wechselwirkung von Korpuskularstrahlen mit Materie . 77

§7. Elementarteilchen in der kosmischen Strahlung . . . . 97

Register zu Band I und II . . . . . . . . . . . . . . 110 